\title{
25. Climate Variability of the Last Five Isotopic Interglacials: Direct Land-Sea-Ice Correlation from the Multiproxy Analysis of North-Western Iberian Margin Deep-Sea Cores
}

\author{
S. Desprat ${ }^{1}$, M. F. Sánchez Goñi ${ }^{1}$, F. Naughton ${ }^{2}$, J.-L. Turon ${ }^{2}$, J. Duprat ${ }^{2}$, B. Malaizé ${ }^{2}$, \\ E. Cortijo ${ }^{3}$ and J.-P. Peypouquet ${ }^{1}$ \\ ${ }^{1}$ EPHE, DGO, UMR-CNRS 5805 EPOC, Université Bordeaux 1, Avenue des Facultés, \\ 33405 Talence, France \\ ${ }^{2}$ Département de Géologie et Océanographie, Université Bordeaux 1, Avenue des \\ Facultés, 33405 Talence, France \\ ${ }^{3}$ Laboratoire des Sciences du Climat et de l'Environnement, LSCE-Vallée, Bât. 12, avenue \\ de la Terrasse, F-91198 Gif-Sur-Yvette cedex, France
}

\begin{abstract}
The last five isotopic interglacials (marine isotope stages 11, 9, 7, 5 and 1) were investigated in Iberian margin deep-sea cores, using terrestrial (pollen) and marine (planktic foraminifera assemblages, benthic and planktic oxygen isotopes) climatic indicators. This work shows that the climatic variability detected on the continent is contemporaneously recorded in the ocean, but temperature changes are not in phase with ice volume variations. The comparison of the different marine isotope stages highlights a common pattern within these stages. They are characterized by three major climatic cycles, related to orbital cyclicity, on which suborbital climatic fluctuations are superimposed. Particularly, suborbital events interrupt the deglacial warming associated with Terminations IV to I and the second major warm period of each isotopic interglacial as well as the transitions towards glacial marine isotope stages. MIS 7 displays a short first warm period $(\sim 8 \mathrm{kyr})$ followed by a striking cold and dry period succeeded by a new strong warmth. In contrast, MIS 11 presents the longest period $(\sim 31 \mathrm{kyr})$ of the last 450000 years.
\end{abstract}

\subsection{INTRODUCTION}

Forecasting the future climatic evolution of the current interglacial is a great challenge. Before that, it is necessary to determine the evolution of past interglacials and evaluate the response of different components of the Earth's climatic system. Owing to the Earth's astronomical configuration, marine isotope stage (MIS) 11 is the best candidate to be the analogue of MIS 1 . However, characterizing the climatic evolution over different situations of insolation forcing will permit better understanding of climate dynamics during interglacial periods. The continental palaeoclimatic records covering the last 425000 years are rare and often fragmentary, and their chronologies are difficult to establish. This impedes the comparison of the climatic changes detected on land with those identified in the oceanic and cryospheric realms.

We present, here, the first direct landsea-ice correlation for the last five isotopic interglacials (MIS 11, 9, 7, 5 and 1). The main purpose of this work was to document the climatic variability of these periods and to assess the phase relationship between the responses of different Earth's environments continent, ocean and ice - to climatic changes in order to discern analogies and 
differences between them. For that, a multiproxy study (pollen, assemblages of planktic foraminifera and $\delta^{18} \mathrm{O}$ of planktic and benthic foraminifera) was performed from several NW Iberian margin deep-sea cores. By comparing the last five isotopic interglacials, we will highlight, on the one hand, the similarities of their climatic dynamics despite different astronomical forcing and, on the other hand, the dissimilarities concerning duration, warmth magnitude and forest succession of the warm periods.

\subsection{PRESENT-DAY}

\section{ENVIRONMENTAL SETTING AND POLLEN SIGNAL IN THE IBERIAN MARGIN}

The Iberian margin deep-sea cores were retrieved $\sim 100 \mathrm{~km}$ off the Galician coast at $\sim 2100 \mathrm{~m}$ of water depth (Fig. 25.1). This site is at present under the influence of the North Atlantic deep water. The northwestern Iberian climate is considered temperate and humid as a result of the influence of dominant Atlantic winds over the year. Mean annual temperature is $12.5^{\circ} \mathrm{C}$ (mean temperature of the coldest month, $\mathrm{MTCO}=5-12^{\circ} \mathrm{C}$; mean temperature of the warmest month, MTWA $=17-22^{\circ} \mathrm{C}$ ) and mean annual precipitation is between 1000 and $2000 \mathrm{~mm} \cdot \mathrm{an}^{-1}$ (Atlas Nacional de España, 1992). This region, incised in the north by the Rias Baixas valleys (Galician coast basin) and the Miño-Sil river (Sil basin) (Atlas Nacional de España, 1993) and crossed in the south by the Douro river, belongs to the Eurosiberian and subMediterranean regions (Ozenda, 1982). At present, deciduous oak woodlands (Quercus robur, Q. pyrenaica and Q. petraea), heaths (Ericaceae including Calluna), brooms (Genista) and gorses (Ulex) dominate the vegetal cover of north-western Iberia (Alcara Ariza et al., 1987).

Studies on present-day pollen deposition in marine sediments show that pollen grains reach marine sites from the adjacent continent by both fluvial and aeolian transport

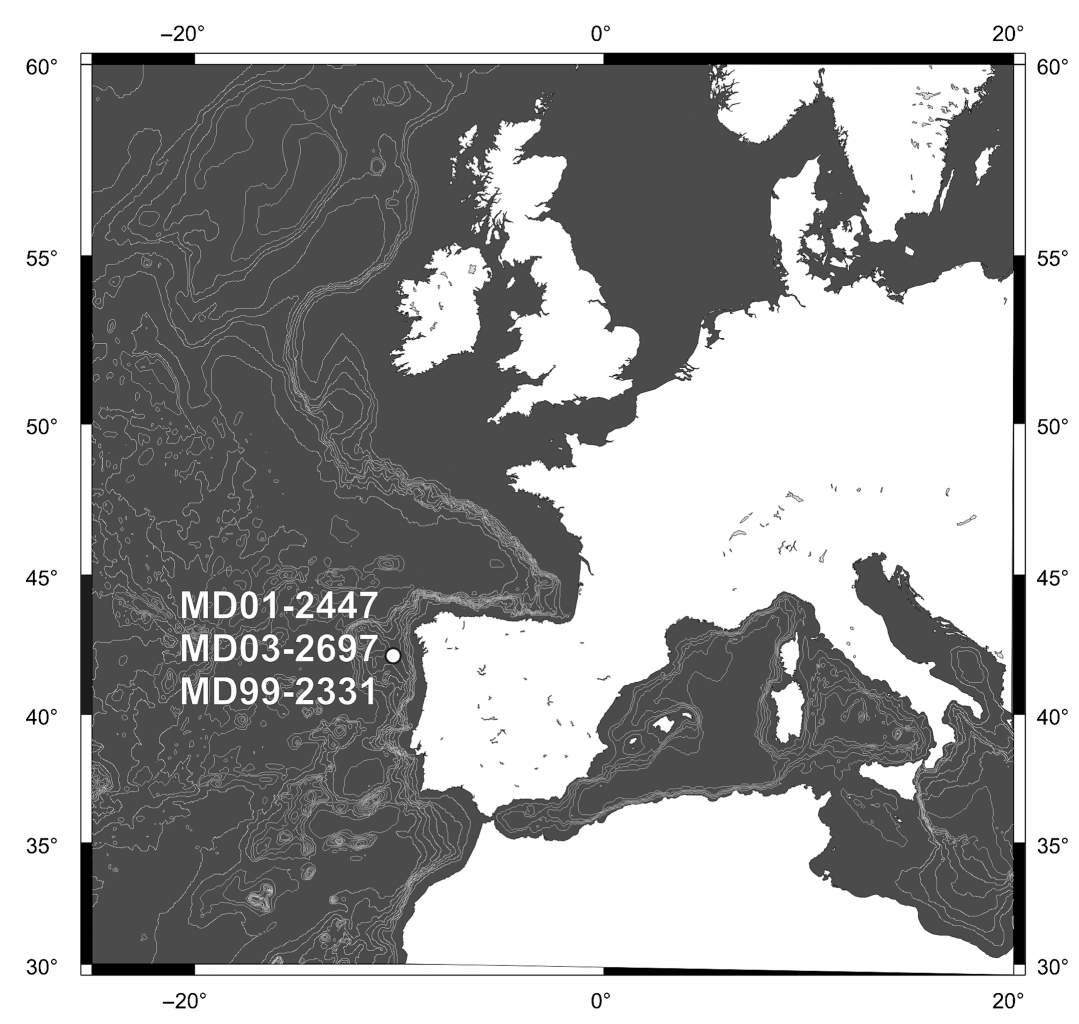

Fig. 25.1 Location of the studied deep-sea cores MD01-2447, MD99-2331 and MD03-2697. 
and subsequent sinking through the water column (Chmura etal., 1999; Dupont and Wyputta, 2003; Heusser, 1978; Heusser and Balsam, 1977). Further, it is suggested that cores located near continental regions with well-developed hydrographic basins and prevailing offshore winds, as it is the case of our cores, mainly recruit pollen from rivers (Heusser, 1978; Turon, 1984; Dupont and Wyputta, 2003). The north-western Iberian rivers, mainly the Douro and Miño and to a lesser extent the Rias Baixas, provide sediments to the shelf area. On the shelf, the fine-particle sediments in suspension are transported northwards by poleward currents, and some are deposited in the Douro and Galicia Mud Patches (Dias et al., 2002). Extreme storm events can produce resuspension of some sediment from the mud patches, and transport of sediments off the shelf can occur (Jouanneau etal., 2002; Vitorino etal., 2002). Pollen grains belonging to the fine-particle fraction have a similar behaviour as fine sediments during the sedimentary processes (Muller, 1959; Chmura and Eisma, 1995). This suggests that pollen grains preserved in our Iberian margin cores mainly come from the Galician and Douro drainage basins. The comparison of marine and continental modern pollen samples with the present-day Iberian vegetation shows that our marine pollen records represent an integrated image of the regional vegetation of the north-western part of the peninsula (Naughton etal., in press).

\subsection{MATERIAL AND METHODS}

Records of pollen and classical climate indicators (planktic foraminafera assemblages, benthic and planktic $\delta^{18} \mathrm{O}$ ) for the last five isotopic interglacials derive from three north-western Iberian margin deep-sea cores (MD01-2447, MD03-2697 and MD992331) (Fig. 25.1). All these cores were retrieved at the same coordinates on board of the oceanographic vessel Marion Dufresne, using the giant corer CALYPSO. As shown in Fig. 25.2, the intervals corresponding to MIS 11, 9 and 7 were studied in

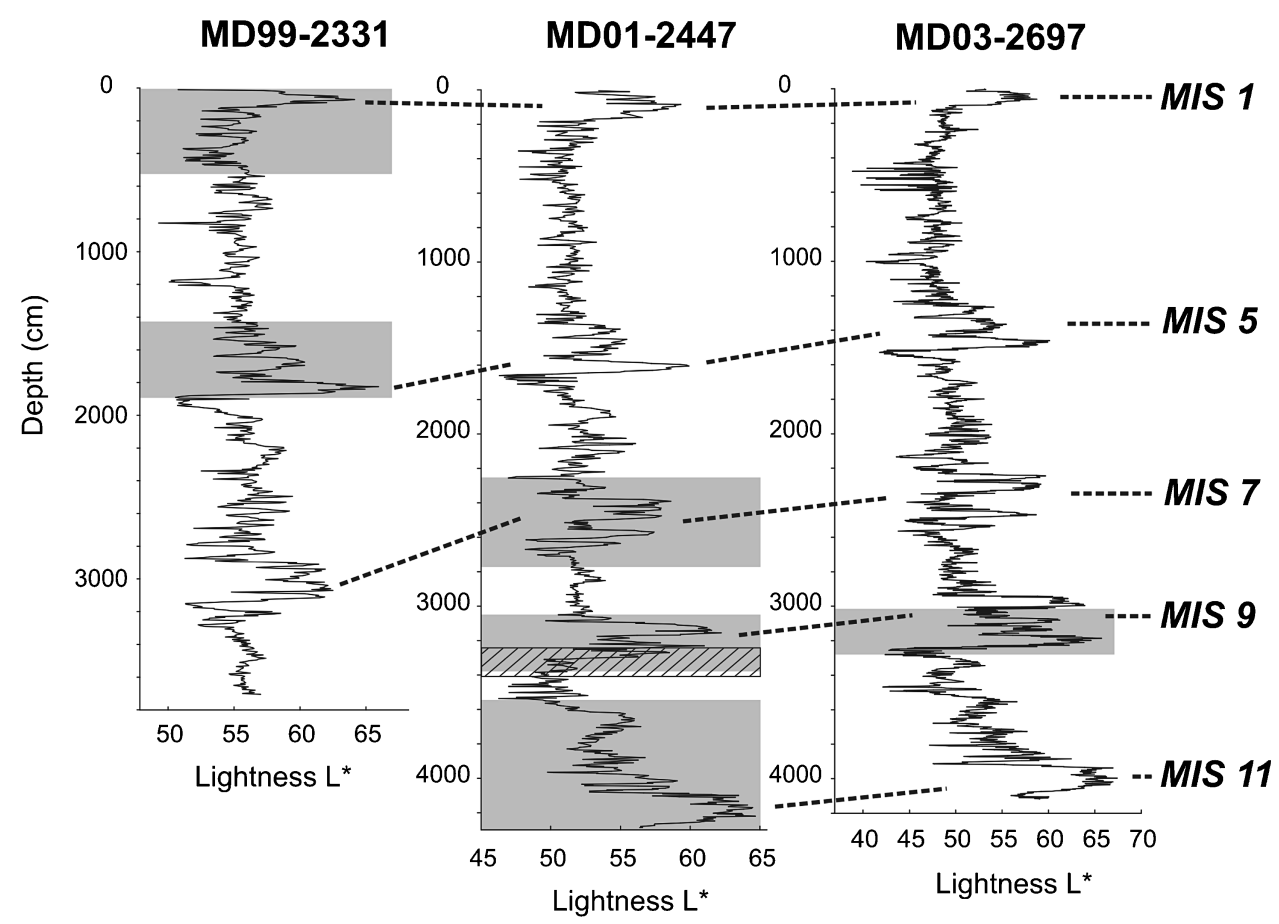

Fig. 25.2 Lightness record of the three Iberian margin deep-sea cores. Pollen analysis has been performed in the intervals represented by grey areas. Hatched area corresponds to the disturbed interval in core MD01-2447. 
core MD01-2447. The beginning of stage 9, being unfortunately disturbed in this core, was studied in the twin core MD03-2697. We present therefore a composite record of MIS 9 built from the correlation of several marine proxies analysed in the twin cores (lightness $\mathrm{L}^{*}, \mathrm{CaCO}_{3}$ content, percentages of N. pachyderma s. and coiling ratio of Globorotalia truncatulinoides) (Desprat, 2005). MIS 1 and 5 records come from the third core MD99-2331 (Naughton etal., in press; Sánchez Goñi et al., 2005).

\subsubsection{Pollen analysis}

Each interval corresponding to MIS 11, 9, 7, 5 and 1 was subsampled for pollen analysis at $10-$ or 5 -cm intervals. The sample preparation technique followed the procedure described by de Vernal etal. (1996) improved at the Département de Géologie et Océanographie, University Bordeaux I (Desprat, 2005). After chemical and physical treatments (cold $\mathrm{HCl}$, cold $\mathrm{HF}$ and sieving through $10-\mu \mathrm{m}$ nylon mesh screens), the residue was mounted unstained in glycerol. Pollen was counted using a Zeiss Axioscope light microscope at 500 and 1250 (oil immersion) magnifications. A minimum of 100 pollen grains excluding the over-represented Pinus grains in marine deposits (Heusser and Balsam, 1977; Turon, 1984) were counted in each of the 327 samples analysed. The pollen percentages for each taxon are based on a main pollen sum that excludes Pinus, aquatic plants, pteridophyte spores and indeterminable pollen grains. Pinus percentages were calculated from the main sum plus Pinus. Spores and aquatic pollen percentages were obtained from the total sum (pollen + spores + indeterminables + unknowns).

\subsubsection{Isotopic analyses}

The sampling resolution interval oscillates between 20 and $2 \mathrm{~cm}$ for Cibicides wuellerstorfi and Melonis barleeanus benthic foraminifera and Globigerina bulloides planktic foraminifera. Each specimen has been picked from the $250-315 \mu \mathrm{m}$ grain-size fraction and cleaned with distilled water. The preparation of each aliquot (four to eight specimens, representing a mean weight of $80 \mu \mathrm{g}$ ) has been done using the Micromass Multiprep autosampler, using an individual acid attack for each sample. The $\mathrm{CO}_{2}$ gas extracted has been analysed against NBS 19 standard, taken as an international reference standard. The isotopic analyses of core MD01-2447 and MD992331 have been carried out at the Département de Géologie et Océanographie (UMR 5805 EPOC, Bordeaux I University, France), using an Optima Micromass mass spectrometer, and those of core MD03-2697 were performed at the Laboratoire des Sciences $d u$ Climat et l'Environnement (Gif-sur-Yvette, France), using a delta plus Finnigan isotope mass spectrometer. All the isotopic results are presented versus PDB. The mean external reproducibility of powdered carbonate standards is $\pm 0.05 \%$ for oxygen.

The $\delta^{18} \mathrm{O}$ values for Cibicides wuellerstorfi and Melonis barleeanus were adjusted by +0.64 per mil and +0.36 per mil, respectively, to account for species-dependent departure from isotopic equilibrium (Shackleton and Opdyke, 1973; Graham et al., 1981; Duplessy et al., 1984; Jansen et al., 1988).

\subsubsection{Chronological framework}

The age model of the intervals corresponding to MIS 11 and 9 is based on the graphical correlation of the benthic $\delta^{18} \mathrm{O}$ curve with the low latitude stack of Bassinot etal. (1994) (Desprat, 2005; Desprat etal., 2005). The chronology of MIS 7 section also derived from a graphical correlation but in this case using the benthic-stack of Martinson et al. (1987) (Desprat etal., 2006).

The chronologies of MIS 5 and 1 are, in contrast, independent of the astronomical calibration. That of the last isotopic interglacial (Sánchez Goñi et al., 2005) is based on the correlation of the major climatic phases 
detected in core MD99-2331 with those identified and dated in the southern Iberian margin core MD95-2042 using the MD952042 chronology of Shackleton et al. (2002). For the interval corresponding to the last 25000 years, the age model was established using the chronology of the climatic episodes identified in other North Atlantic records and the ages assigned to several well-dated botanical events in the Iberian Peninsula.

\subsection{THE CLIMATIC VARIABILITY OF THE LAST FIVE ISOTOPIC INTERGLACIALS IN AND OFF NW IBERIA}

\subsubsection{General climatic dynamic}

During the last five isotopic interglacials, the warm periods in north-western Iberia are characterized by the development of the temperate and humid forest, principally deciduous oak. In turn, open vegetation dominated by Poaceae and Asteraceae, with some semidesert plants, or mainly composed of heathland, expands during cold periods. The recorded vegetation changes indicate that climate has strongly oscillated during the previous isotopic interglacials.

The climatic evolution detected on the continent parallels the oceanic changes reflected by marine proxies (planktic foraminifera $\delta^{18} \mathrm{O}$ and percentages). Indeed, each cold episode is marked by an increase of the percentages of the polar planktic foraminifera $N$. pachyderma s. and heavier planktic $\delta^{18} \mathrm{O}$ values. The record of planktic foraminifera assemblages is only available for MIS 11, 9 and 7. It shows that the tropical and summer subtropical species generally reach their maximal development during the warm periods detected on the continent. During each of the Terminations I to IV, an abrupt cold event interrupts the development of the temperate and humid forest associated with the deglacial warming: Younger Dryas, post-Zeifen stadial,
MD47-7-S1 and MD47-9-S1 (Fig. 25.3). These cold events have a clear imprint in the oceanic realm, in particular that of Termination IV. These coolings appear to be of different magnitude and during Terminations II, III and IV, they occur at the onset of minimum ice volume. For example, MD47-8-I1/MD47-7-S1 cycle shows the strongest amplitude of vegetation changes. The occurrence of such an episode during Termination $\mathrm{V}$ is still unknown because our sedimentary core does not cover the whole MIS12/MIS11 transition.

As suggested by long European pollen sequences (Reille et al., 1998, 2000; Tzedakis et al., 2001), our direct land-sea-ice correlation confirms that on the continent each isotopic interglacial is characterized by three major warm periods associated with low ice volume, in response to the astronomical forcing (Table 25.1, Fig. 25.3). Indeed, the major forested periods in north-western Iberia are associated with low ice volume contrasting with the open vegetation phases related with ice cap development. Nevertheless, our direct land-sea-ice correlation puts forward that the ice volume changes are not synchronous with the temperature shifts on the continent and in the ocean. As observed by Sánchez Goñi et al. $(1999,2005)$, Shackleton etal. (2002) and Tzedakis etal. (2004), the limits of isotopic substages do not correspond to those of the climatic phases detected in western Iberia. For example, the Eemian in Iberia does not correspond to the entire MIS 5e (Sánchez Goñi et al., 1999, 2005; Shackleton et al., 2002).

During the isotopic interglacials MIS 11, 9, 7 and 5, the first major warm periods (Vigo, Pontevedra, Arousa and Eemian) are marked by a more developed forest than the following ones. This is particularly true for MIS 11. Indeed, the climate optimum of each stage, detected by the maximal expansion of oak forest, Mediterranean plants and the maximal contraction of pine woodlands, occurs during these first major warm periods. These climate optima are contemporaneous to the ice volume minimum of each 


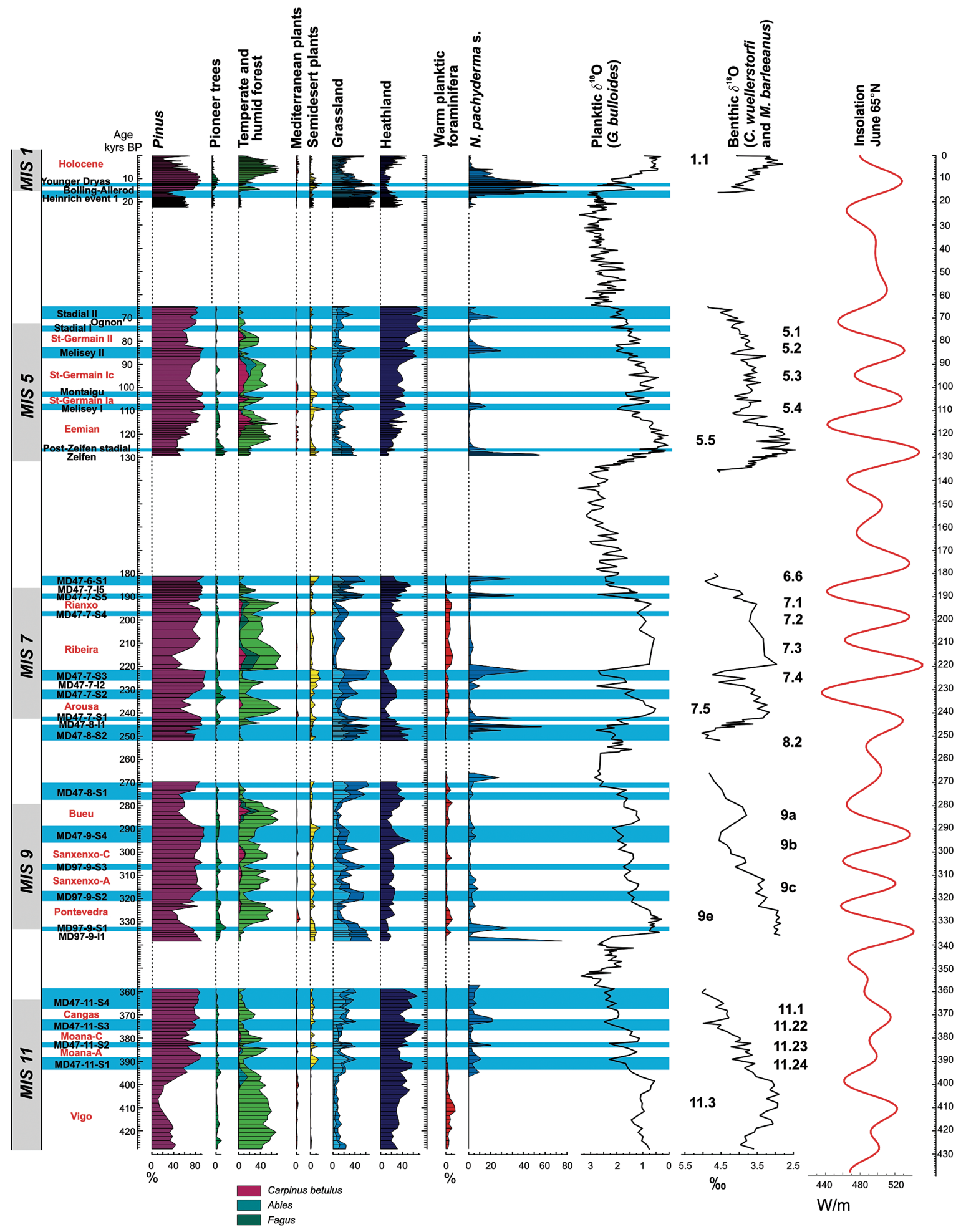

Fig. 25.3 Direct correlation of continental and marine proxies from Iberian margin deep-sea cores. From the left to the right: (1) Synthetic pollen diagram; (2) Percentages of warm planktic foraminifera (only for MIS 7, 9 and 11) and Neogloboquadrina pachyderma left coiling; (3) Planktic $\delta^{18} O$ curve; (4) Benthic $\delta^{18} \mathrm{O}$ curves. For the last 25000 years, the benthic isotopic data of core MD99-2331 being not available, we present those of core MD01-2447. The correlation between both cores has been performed using different marine proxies (lightness, $\mathrm{CaCO}_{3}$ content, abundance and coiling ratio of Globorotalia hirsuta and G. truncatulinoides and percentages of N. pachyderma s.) (Desprat, 2005); (5) June insolation at $65^{\circ} \mathrm{N}$. Blue areas indicate cold periods. 
Table 25.1 Major warm periods detected in north-western Iberia during the last 425000 years versus marine isotopic stratigraphy

\begin{tabular}{lll}
\hline $\begin{array}{l}\text { Marine Isotope } \\
\text { Stages }\end{array}$ & $\begin{array}{l}\text { Isotopic } \\
\text { events }\end{array}$ & $\begin{array}{l}\text { Iberian major } \\
\text { warm periods }\end{array}$ \\
\hline MIS 1 & 1.1 & Holocene \\
MIS 5 & 5.1 & St. Germain II \\
& 5.3 & St. Germain I \\
& 5.5 & Eemian \\
MIS 7 & 7.1 & Rianxo \\
& 7.3 & Ribeira \\
MIS 9 & 7.5 & Arousa \\
& $9 \mathrm{a}$ & Bueu \\
& $9 \mathrm{c}$ & Sanxenxo \\
MIS 11 & $9 \mathrm{e}$ & Pontevedra \\
& 11.1 & Cangas \\
& 11.23 & Moana \\
\hline
\end{tabular}

The time lags between the boundaries of isotopic substages and stages and those of forested phases are not indicated.

stage. However, MIS 7 presents another particularity most likely related to especially strong insolation maximum: the second major warm period (Ribeira) is also marked by strong expansion of the temperate and humid forest, development of warm planktic foraminifera and important ice volume decrease. This implies that Ribeira would be, at least, as warm as the Arousa interglacial. Therefore, MIS 7 displays two climatic optima both associated with low ice volume as shown by the benthic isotopic record.

The Vigo, Pontevedra and Eemian interglacials are followed by a strong cold period (MD47-11-S1, MD97-9-S2 and Mélisey I). In contrast, MIS 7 includes a suborbital cycle (MD47-7-S2/MD47-7-I2) between the Arousa interglacial and the strong cold period MD47-7-S3.

MD47-7-S3 was the coldest and driest period on the continent of the last five isotopic interglacials, as indicated by the highest values of grassland and semidesert taxa of our pollen record. This phase is also marked by the strongest decrease of sea-surface temperatures as shown by the maximum percentages of $N$. pachyderma left coiling. This cold episode is also coeval with the largest ice volume increase (MIS 7.4) of the last isotopic interglacials, being similar to the glacial maximum of MIS 8. These unusual very cold conditions and huge icesheet enlargement within an isotopic interglacial are also recorded in northern North Atlantic ODP sites 983 and 980 (Channell etal., 1997; McManus etal., 1999). It is remarkable that this episode occurs during the most important insolation minimum of the last 450000 years.

Other suborbital events are superimposed on this orbital climatic variability. The Vigo interglacial is marked by two cool events circa 417 and $40 \mathrm{kyr}$, having a clear influence on vegetation and planktic foraminifera. More especially, the temperate and humid forest developments associated with the second major warm periods of MIS 11, 9 and 5 (Moana, Sanxenxo, St-Germain I) are all interrupted by a cold episode (MD47-11-S1, MD97-9-S2 and Montaigu, respectively). After our age model, these cold events are short, between 2 and 4 kyr. Moreover, during these episodes, the benthic $\delta^{18} \mathrm{O}$ values become heavier, in particular during MD97-9-S2. This indicates a significant increase of ice volume during the cold event within MIS 9c, as shown by Tzedakis etal. (2004). These cold fluctuations are also clearly recorded in the Velay sequence (Reille etal., 2000). In contrast, MIS 7 does not show such a climatic event.

During the interglacial-glacial transitions MIS 7-MIS 6 and MIS 5-MIS 4, another climatic cycle of minor order is detected. The cooling associated with the MIS 9-MIS 8 transition seems also to be interrupted by a warm oscillation which needs to be confirmed by supplementary analysis. Nonetheless, all these warm events are clearly recorded in the oceanic realm by light values of planktic $\delta^{18} \mathrm{O}$ and an increase of warm planktic percentages.

In sum, in spite of the different astronomical configuration of the last five isotopic interglacials, a common climatic evolution pattern emerges. However, each warm phase is characterized by different duration, amplitude and forest succession. 


\subsubsection{Warmth amplitudes of the last 450000 years}

At present, the different amplitudes of warmth during the last 450000 years are discussed. The results are often contradictory, depending on the regions and proxies concerned. Some works suggest that the warmest phase of MIS 11 shows the highest temperatures of the last 500000 years (Howard, 1997; Droxler and Farrel, 2000; Berstad et al., 2002). However, this idea is challenged by many works (Bauch etal., 2000; Hodell et al., 2000; Kunz-Pirrung etal., 2002; McManus etal., 2003) which have shown that MIS 11 was not warmer than today. The deuterium signal of Vostok ice-core records the highest temperatures for MIS 9 (Petit et al., 1999), but the recent results of EPICA-Dome $\mathrm{C}$ ice core do not confirm this idea (EPICA Community Members, 2004). These new data also show higher temperatures in Antarctica during MIS 11 than during the Holocene (EPICA Community Members, 2004).

As previously shown, in our record, each isotopic stage displays its climate optimum during the first warm period, excepting MIS 7 which presents a second optimum during Ribeira. The first optimum of this isotopic interglacial, Arousa, is marked by the highest percentages of temperate and humid trees. However, Mediterranean plants are scantily represented during this interval and only by evergreen Quercus which does not reveal clear Mediterranean conditions. In contrast, although the Vigo, Ribeira, Eemian and Holocene interglacials are characterized by lower percentages of temperate and humid forest than those during the Arousa interglacial, they record true Mediterranean species such as Pistacia, Olea or Cistus. For this reason, it remains difficult to determine which period is the warmest of the last five climatic cycles in northern Iberia.

The warm planktic foraminifera record of MIS 11, 9 and 7 indicates the highest seasurface temperatures during MIS 11 climatic optimum. However, the development of these warm foraminifera is only slightly stronger than during the other climatic optima. Therefore, the Vigo interglacial may be the warmest period of the last 450000 years, but the difference of temperature does not appear large. Moreover, the benthic isotopic signal does not display weaker ice volume during Vigo interglacial than during Pontevedra, Ribeira, Eemian or Holocene interglacials. The genesis of such a warm interglacial during MIS 11 remains still a mystery in palaeoclimatology taking into account the weak insolation forcing.

\subsubsection{Duration of the forest phases}

MIS 11 is marked by a long first major warm period, lasting $\sim 31 \mathrm{kyr}$ after our age model. The Vigo interglacial appears two times longer than the Eemian ( $16 \mathrm{kyr})$, and at least three times longer than the Pontevedra and Arousa interglacials ( $\sim 11$ and $8 \mathrm{kyr}$, respectively). The Holocene began 10000 years ago, and it is already longer than the Arousa interglacial.

On the basis of the pollen analysis of the south-western Iberian margin deep-sea core MD01-2443, Tzedakis etal. (2004) and Roucoux etal. (this volume) suggest a very short forest phase during MIS 9e, lasting 3600 years, after which Ericaceae expand. To bypass the difference in duration inferred from the age models, we have tuned our planktic $\delta^{18} \mathrm{O}$ record to that of MD01-2443. After this exercise, the resulting duration of the Pontevedra period is 13000 years. It is possible that the cold/arid event responsible for the shortening of the first warm period of MIS 9 in south-western Iberia is not shown by our sequence due to a too low-resolution analysis. However, our results do not suggest that this abrupt climatic deterioration detected in southwestern Iberia brings the first MIS 9 forest period to an end in the north-western part of the Peninsula. In the same way, the Praclaux sequence (Massif Central, France) also records a long warm period even if it includes a slight forest reduction (Tzedakis etal., 2004). 
Our observation confirms, despite the uncertainties associated with the age scale of our record, that the warmest period of MIS 11 would be longer than those of the following isotopic interglacial stages, and so far three times longer than the Holocene.

\subsubsection{Forest successions}

The warm periods of our record are marked by the development of pioneer trees, principally Betula, followed by the expansion of deciduous oak and hazel. This is in agreement with the classical vegetational succession during interglacial periods in northern Europe, as described by van der Hammen et al. (1971). This ideal succession sees at the latest stages the expansion of hornbeam, beech, fir, finishing with the development of the boreal forest with spruce. In the north-western Iberian region, the boreal forest phase is never reached during the warm periods. Moreover, the expansion of latecomer trees is different from one period to another:

- Abies strongly developed only at the end of the Vigo interglacial and St. Germain Ic and it was only present at the end of the Eemian and Bueu (the last forested period of MIS 9).

- Carpinus betulus expanded in the second part of all first major warm phases when deciduous Quercus decreased except during the Holocene. However, the hornbeam expansion was very strong during the Eemian, weaker during the Pontevedra and Arousa interglacials and very weak during the Vigo interglacial. During the other warm periods, hornbeam had also its maximal expansion after that of deciduous oak.

- Fagus never had an important expansion at the end of the first major warm phases. Beech is only sporadically recorded at the end of the Vigo and Pontevedra interglacials. In contrast, during the periods Bueu, Ribeira and Rianxo, Fagus plays an important role in the vegetal cover of the north-western Iberian region, always associated with Carpinus betulus. It is also noteworthy that beech developed rapidly and strongly at the beginning of the Ribeira interglacial (Desprat et al., 2006).

The different behaviour of these three trees, depending on the periods and regions, has been previously noticed by Tzedakis and Bennett (1995) and Tzedakis etal. (2001). Disentangling the factors responsible for the settlement of tree species in a given region and period is a difficult task. The late expansion of some tree species can be linked: (a) to their migration rate in relation to their own dispersion mechanisms such as reproduction or seed scattering and with their competencies to develop on more or less mature soils, (b) to the distance to the glacial refugial zone, (c) to the interspecific competition, (d) to the individual response of each species to climatic change, and (e) also to the direct effect of the climate (Huntley and Webb, 1989; Huntley, 1996). Climate can also play an indirect role in changing the interspecific relationships (Lischke etal., 2002). Small differences in climatic conditions at the beginning of a warm phase can also influence the development of the late expanding trees (i.e. Carpinus, Abies and Fagus) (Tzedakis etal., 2001). Moreover, reduced diversity of taxa such as Fagus, Carpinus and Abies may imply that they are more susceptible to disease or adverse climatic conditions (Tzedakis etal., 2001). During a short warm period such as the Arousa interglacial, the virtual absence of beech and fir in north-western Iberia may be associated with a too little time for migrating from faraway refugial areas to the Iberian Peninsula, likely in relation to their own migration mechanisms. Nevertheless, the biotic processes cannot explain the very late arrival of Fagus in north-western Iberia, approximately 25000 years after the beginning of the Vigo interglacial, since it developed only 7000 years after the beginning of the 
Pontevedra interglacial. Therefore, the different timing and magnitude of the expansion of the late succession trees is somehow linked to the inherent climatic conditions of each warm phase of the different isotopic interglacials, which are related to ice-sheet extension and to the orbital parameters.

\subsection{CONCLUSIONS}

This work constitutes a new step in documenting the climatic variability of interglacial isotopic stages. It provides the first direct land-sea-ice correlation of the last five isotopic interglacials (MIS 1, 5, 7, 9 and 11) from the multiproxy analysis of three pollen-rich cores from the northwestern Iberian margin. This record puts forward the phasing, previously identified during MIS 5, between changes in oceanic surface conditions and continental climate during the previous isotopic interglacials. Despite the differences of astronomical forcing, several similarities between these isotopic stages emerge: (a) the occurrence of three major climatic cycles, related to orbital cyclicity, (b) a climatic optimum during the first major warm periods, associated with ice volume minimum, (c) a suborbital cold event interrupting the second major warm period and (d) a suborbital climatic instability during the glacial-interglacial and interglacial-glacial transitions.

The largest insolation oscillations controlling MIS 7 may explain the discrepancies between the climatic variability of this isotopic interglacial and the observed general scheme: a second major warm period at least as warm as the first one and preceded by a very cold and dry episode associated with an unusual important ice volume. Another striking feature of this stage is the very short first warm period, the Arousa interglacial, which is even shorter than the Holocene. In contrast, MIS 11 presents the longest warm period (Vigo interglacial) of the last 450000 years, three times longer than our present interglacial.

\section{ACKNOWLEDGEMENTS}

Financial support was provided by IPEV and PNEDC French programs. We thank logistics and coring teams on board of the R/V Marion Dufresne II during the Ginna, Geosciences and Picabia oceanographic cruises and Marie-Hélène Castera, Karine Charlier, Olivier Ther and Françoise Vinçon for invaluable technical assistance. This paper is Bordeaux 1 University, UMRCNRS 5805 EPOC Contribution n ${ }^{\circ} 1591$.

\section{REFERENCES}

Alcara Ariza, F., Asensi Marfil, A., de Bolos y Capdevilla, O., Costa Tales, M., Arco Aguilar, M., Diaz Gonzales, T.E., Diez Garretas, B., Fernandez Prieto, J.A., Fernandez Gonzales, F., Izco Sevillando, J., Loidi Arregui, J., Martinez Parras, J.M., Navarro Andres, F., Ninot I Sugranes, J.M., Peinado Lorca, M., Rivas Martinez, S., Sánchez Mata, D., Valle Guitierrez, C., Vigo I Bonada, J., Wildpret de la Torre, W., 1987. La vegetación de España. Collection Aula Abierta. Universidad de Alcala de Henares, 544 pp.

Atlas Nacional de España, C., 1992. Ministerio de Obras Publicas y Transportes, Direccion General del Instituto Geografico Nacional, Madrid.

Atlas Nacional de España, H., 1993. Ministerio de Obras Publicas, Transportes y Medio Ambiente, Direccion General del Instituto Geografico Nacional, Madrid.

Bassinot, F.C., Labeyrie, J.D., Vincent, E., Quidelleur, X., Shackleton, N.J., Lancelot, Y., 1994. The astronomical theory of climate and the age of the Brunhes-Matuyama magnetic reversal. Earth and Planetary Science Letters 126, 91-108.

Bauch, H.A., Erlenkeuser, H., Helmke, J.P., Struck, U., 2000. A paleoclimatic evaluation of marine oxygen isotope stage 11 in the high-northern Atlantic (Nordic seas). Global and Planetary Change 24, 27-39.

Berstad, I.M., Lundberg, J., Lauritzen, S.E., Linge, H.C., 2002. Comparison of the climate during Marine Isotope Stage 9 and 11 inferred from a speleothem isotope record from Northern Norway. Quaternary Research 58, 361-371. 
Channell, J.E.T., Hodell, D.A., Lehman, B., 1997. Relative geomagnetic paleointensity and $\delta^{18} \mathrm{O}$ at site ODP 983 (Gardar Drift, North Atlantic) since $350 \mathrm{ka}$. Earth and Planetary Science Letters 153, 103-118.

Chmura, G.L., Eisma, D., 1995. A palynological study of surface and suspended sediments on a tidal flat: implications for pollen transport and deposition in coastal waters. Marine Geology 128, 183-200.

Chmura, G.L., Smirnov, A., Campbell, I.D., 1999. Pollen transport through distributaries and depositional patterns in coastal waters. Palaeogeography, Palaeoclimatology, Palaeoecology 149, 257-270.

de Vernal, A., Henry, M., Bilodeau, G., 1996. Techniques de préparation et d'analyse en micropaléontologie. Les cahiers du GEOTOP 3, 16-27.

Desprat, S., 2005. Réponses climatiques marines et continentales du Sud-Ouest de l'Europe lors des derniers interglaciaires et des entrées en glaciations. Thèse doctorale, Université Bordeaux I, Talence, $272 \mathrm{pp}$.

Desprat, S., Sánchez Goñi, M.F., Turon, J.-L., McManus, J.F., Loutre, M.F., Duprat, J., Malaizé, B., Peyron, O., Peypouquet, J.-P., 2005. Is vegetation responsible for glacial inception during periods of muted insolation changes? Quaternary Science Reviews 24, 1361-1374.

Desprat, S., Sánchez Goñi, M.F., Turon, J.-L., Duprat, J., Malaizé, B., Peypouquet, J.-P., 2006. Climatic variability of Marine Isotope Stage 7: direct land-sea-ice correlation from a multiproxy analysis of a northwestern Iberian margin deep-sea core. Quaternary Science Reviews 25 (9-10), 1010-1026.

Dias, J.M.A., Jouanneau, J.M., Gonzalez, R., Araujo, M.F., Drago, T., Garcia, C., Oliveira, A., Rodrigues, A., Vitorino, J., Weber, O., 2002. Present day sedimentary processes on the northern Iberian shelf. Progress in Oceanography 52, 249-259.

Droxler, A.W., Farrell, J.W., 2000. Marine Isotope Stage (MIS 11): new insights for a warm future. Global and Planetary Change 24, 1-5.

Duplessy, J.-C., Shackleton, N.J., Matthews, R.K., Prell, W., Ruddiman, W.F., Caralp, M., Hendy, C.H., 1984. ${ }^{13} \mathrm{C}$ record of benthic Foraminifera in the last interglacial ocean: implication for carbon cycle and the global deep water circulation. Quaternary Research 21, 225-243.

Dupont, L., Wyputta, U., 2003. Reconstructing pathways of aeolian pollen transport to the marine sediments along the coastline of SW Africa. Quaternary Science Reviews 22, 157-174.

EPICA Community Members, 2004. Eight glacial cycles from an Antarctic ice core. Nature 429, 623-628.
Graham, D.W., Corliss, B.H., Bender, M.L., Keigwin, D., 1981. Carbon and oxygen disequilibria of recent deep-sea benthic foraminifera. Marine micropaleontology 6, 483-497.

Heusser, L., 1978. Spores and pollen in the marine realm. In: Haq, B. U., Boersma, A. (Eds.), Introduction to marine micropaleontology. Elsevier, New York, pp. 327-339.

Heusser, L.E., Balsam, W.L., 1977. Pollen distribution in the N. E. Pacific Ocean. Quaternary Research 7, 45-62.

Hodell, D.A., Charles, C.D., Ninnemann, U.S., 2000. Comparison of interglacial stages in the South Atlantic sector of the southern ocean for the past $450 \mathrm{kyr}$ : implications for Marine Isotope Stage (MIS) 11. Global and Planetary Change 24, 7-26.

Howard, W.R., 1997. A warm future in the past. Nature 388, 418-419.

Huntley, B., 1996. Quaternary paleoecology and ecology. Quaternary Science Reviews 15, 591-606.

Huntley, B., Webb III, T., 1989. Migration: species' response to climatic variations caused by changes in the Earth's orbit. Journal of Biogeography 16, 5-19.

Jansen, E., Bleil, U., Henrich, R., Kringstad, L., Slettemark, B., 1988. Paleoenvironmental changes in the Norwegian sea and the northeast Atlantic during the last 2.8 m.y.: deep sea drilling project/ocean drilling program sites $610,642,643$ and 644 . Paleoceanography 3, 563-581.

Jouanneau, J.M., Weber, O., Drago, T., Rodrigues, A., Oliveira, A., Dias, J.M.A., Garcia, C., Schimdt, S., Reyss, J.L., 2002. Recent sedimentation and sedimentary budget on the western Iberian shelf. Progress in Oceanography 52, 261-275.

Kunz-Pirrung, M., Gersonde, R., Hodell, D.A., 2002. Mid-Brunhes century-scale diatom sea surface temperature and sea ice records from the Atlantic sector of the Southern Ocean (ODP Leg 177, sites 1093, 1094 and core PS2089-2). Palaeogeography, Palaeoclimatology, Palaeoecology 182, 305-328.

Lischke, H., Lotter, A.F., Fischlin, A., 2002. Untangling a Holocene pollen record with forest model simulations and independent climate data. Ecological Modelling 150, 1-21.

Martinson, D.G., Pisias, N.G., Hays, J.D., Imbrie, J., Moore, T.C., Shackleton, N.J., 1987. Age dating and orbital theory of the Ice Ages: Development of a high-resolution 0 to 300,000-year chronostratigraphy. Quaternary Research 27, 1-29.

McManus, J.F., Oppo, D.W., Cullen, J.L., 1999. A 0.5-million-year record of millennial-scale climate variability in the North Atlantic. Science 283, 971-975.

McManus, J., Oppo, D., Cullen, J., Healey, S., 2003. Marine isotope stage 11 (MIS 11): analog for Holocene and future climate. In: Droxler, A.W., Poore, R.Z., Burckle, L.H. (Eds.), Earth's climate and orbital 
eccentricity: the marine isotope stage 11 question. Geophysical Monograph. American Geophysical Union, Washington, DC, pp. 69-85.

Muller, J., 1959. Palynology of recent Orinoco delta and shelf sediments. Micropaleontology 5, 1-32.

Naughton, F., Sánchez Goñi, M.F., Desprat, S., Turon, J.-L., Duprat, J., Malaizé, B., Joly, C., Cortijo, E., Drago, T., Freitas, M.C., in press. Present-day and past (last 25000 years) Marine pollen signal off Western Iberia. Marine Micropaleontology.

Ozenda, P., 1982. Les végétaux dans la biosphère. Doin, Paris, 431 pp.

Petit, J.R., Jouzel, J., Raynaud, D., Barkov, N.I., Barnola, J.-M., Basile, I., Bender, M., Chappellaz, J., Davis, M., Delaygue, G., Delmotte, M., Kotyakov, V.M., Legrand, M., Lipenkov, V.Y., Lorius, C., Pépin, L., Ritz, C., Saltzman, E., Stievenard, M., 1999. Climate and atmospheric history of the past 420000 years from the Vostok ice core, Antarctica. Nature 399, 429-436.

Reille, M., Andrieu, V., de Beaulieu, J.-L., Guenet, P., Goeury, C., 1998. A long pollen record from Lac du Bouchet, Massif Central, France: for the period ca. 325 to $100 \mathrm{ka}$ BP (OIS 9c to OIS 5e). Quaternary Science Reviews 17, 1107-1123.

Reille, M., de Beaulieu, J.-L., Svobodova, V., AndrieuPonel, V., Goeury, C., 2000. Pollen analytical biostratigraphy of the last five climatic cycles from a long continental sequence from the Velay region (Massif Central, France). Journal of Quaternary Science 15, 665-685.

Roucoux, K.H., Tzedakis, P.C., de Abreu, L., Shackleton, N.J. (this volume). Fine tuning the land-ocean correlation for the late Middle Pleistocene of southern Europe. The climate of the past interglacials.

Sánchez Goñi, M.F., Eynaud, F., Turon, J.-L., Shackleton, N.J., 1999. High resolution palynological record off the Iberian margin: direct land-sea correlation for the Last Interglacial complex. Earth and Planetary Science Letters 171, 123-137.

Sánchez Goñi, M.F., Loutre, M.F., Crucifix, M., Peyron, O., Santos, L., Duprat, J., Malaizé, B.,
Turon, J.-L., Peypouquet, J.-P., 2005. Increasing vegetation and climate gradient in western Europe over the Last Glacial Inception (122-110 ka): models-data comparison. Earth and Planetary Science Letters 231, 111-130.

Shackleton, N.J., Opdyke, N.D., 1973. Oxygen isotope and paleomagnetic stratigraphy of Equatorial Pacific core V28-238: oxygen isotope temperatures and ice volumes on a $10^{5}$ year and $10^{6}$ year scale. Quaternary Research 3, 39-55.

Shackleton, N.J., Chapman, M., Sánchez Goñi, M.F., Pailler, D., Lancelot, Y., 2002. The classic marine isotope substage 5e. Quaternary Research 58, 14-16.

Turon, J.-L., 1984. Le palynoplancton dans l'environnement actuel de l'Atlantique nord-oriental. Evolution climatique et hydrologique depuis le dernier maximum glaciaire. Mémoires de l'Institut de Géologie du bassin d'Aquitaine 17. Université de Bordeaux I, Bordeaux, 313 pp.

Tzedakis, P.C., Bennett, K.D., 1995. Interglacial vegetation succession: a view from southern Europe. Quaternary Science Reviews 14, 967-982.

Tzedakis, P.C., Andrieu, V., de Beaulieu, J.-L., Birks, H.J.B., Crowhurst, S., Follieri, M., Hooghiemstra, H., Magri, D., Reille, M., Sadori, L., Shackleton, N.J., Wijmstra, T.A., 2001. Establishing a terrestrial chronological framework as a basis for biostratigraphical comparisons. Quaternary Science Reviews 20, 1583-1592.

Tzedakis, P.C., Roucoux, K.H., de Abreu, L., Shackleton, N.J., 2004. The duration of forest stages in southern Europe and interglacial climate variability. Science 306, 2231-2235.

van der Hammen, T., Wijmstra, T.A., Zagwijn, W.H., 1971. The floral record of the Late Cenozoic of Europe. In: Turekian, K.K. (Ed.), The Late Cenozoic glacial ages. Yale University Press, New Haven, pp. 391-424.

Vitorino, J., Oliveira, A., Jouanneau, J.M., Drago, T., 2002. Winter dynamics on the northern Portuguese shelf. Part 2: bottom boundary layers and sediment dispersal. Progress in Oceanography 52, 155-170. 